Original Research

\title{
The Impact of Independent of Activity Daily Living among Stroke Patients on Caregivers Burden
}

\author{
Nikmatul Fadilah and Loetfia Dwi Rahariyani \\ Polytechnic of Health, Ministry of Health, Surabaya, Indonesia
}

\begin{abstract}
Introduction: Weakness among stroke patients causes obstacles when fulfilling their activities in daily living (ADL). This condition also has an impact on the caregivers who provide daily care at home. The purpose of this study was to analyze the effect of independent ADL among the stroke patients on caregiver burden.

Methods: The study used an analytical design through a cross-sectional approach. The variables included independent ADL and caregiver burden. A sample of 120 caregivers was taken from 2 community health centers in Surabaya through simple random sampling. The instruments used were Zarit Burden's Interview Schedule and the Katz Index of Independent for ADL. Regression ordinal was used to analyze the influence of independent ADL among stroke patients on caregiver burden.

Results: The results showed that the caregiver who take care of stroke patients with severe functional impairment will feel burdened 3 times more than no burden. Post-stroke care at home through a rehabilitation program plays an important role in improving the condition of patients and their families at home, especially the caregivers.

Conclusion: Nurses in a community health center through the family health care pathway provide comprehensive bio-psycho-socio-spiritual care in the rehabilitation period as expected. They are expected to improve and maintain the fulfillment of human needs comprehensively for stroke patients and their caregivers, so the quality of life of stroke patients, caregivers and their families remains optimal.
\end{abstract}

\section{ARTICLE HISTORY}

Received: December 26, 2019

Accepted: December 31, 2019

\section{KEYWORDS}

independent; daily living; strong; caregiver burden

\section{CONTACT}

Nikmatul Fadilah

\nikmatulf@poltekkesdepkessby.ac.id

$\leqq$ Polytechnic of Health, Ministry of Health, Surabaya, Indonesia

Cite this as: Fadilah, N. \& Rahariyani, L. D. (2019). The Impact of Independent of Activity Daily Living among Stroke Patients on Caregivers Burden. Jurnal Ners, 14(3si), 188-194. doi:http://dx.doi.org/10.20473/jn.v14i3(si).17047

\section{INTRODUCTION}

Brain damage due to non-traumatic cerebral circulatory disorders is increasing in society today. This is known as a stroke, which can happen suddenly, progressively and quickly. The prevalence of stroke in East Java in 2013 was 16 and it was included in the top four causes of death in Indonesia. Although the prevalence decreased in 2018 which was equal to $12.4 \%$, East Java was still included in the 8 major provinces concerning the prevalence of stroke cases. Stroke attacks cause symptoms in the form of paralysis of the face or limbs, the speech not being smooth or clear (disartria), changes in consciousness, impaired vision, difficulty in swallowing and speaking and difficulty understanding the conversations of other. These symptoms can settle after the acute phase (RISKESDAS, 2018)(Badan Penelitian \& dan Pengembangan Kesehatan, 2013). Changes in the conditions experienced by post-stroke patients, especially the presence of weakness or paralysis of the limbs, causes the patients to experience obstacles when fulfilling their activities of daily living. Some of them experience dependency in living their lives and some even claim that their quality of life decreases(Bakas et al., 2014)(Handayani \& Dewi, 2009)(Karunia, 2016)(Ogunlana, Dada, Oyewo, Odole, \& Ogunsan, 2014).

Stroke patients and families feel that they are in a crisis situation, not only in the acute phase of hospital care. This situation may continue until after the treatment in the hospital, namely the rehabilitative 
period. The condition of the patients with sequelae after a stroke is a new situation for the patients and their families. Changes in their physical health condition, especially weakness or paralysis, are also a crisis situation for the patients. The family will carry out additional roles to maintain a more healthy condition for their family member with a stroke, especially when it comes to providing care to meet the basic needs of the stroke patients at home. A previous study showed that $10 \%$ of stroke patients were dependent on meeting their ADLs in the category of moderate dependence, severe dependence and total dependence, while mild dependence reached $70 \%$ (Setyoadi \& Wihastuti, 2018). The dependence on fulfilling ADL causes burnout syndrome for caregivers. The study by Kumar (2015) of 100 caregivers looking after stroke survivors from a selected community setting and the outpatient department of different tertiary care hospitals in Punjab showed that $63 \%$ experienced a mild to moderate burden, $28 \%$ experienced no burden, $7 \%$ experienced a moderate to severe burden and $2 \%$ experienced a severe burden(Kumar, Roy, \& Kar, 2012). Other previous studies about the burden of the informal caregivers of stroke survivor in secondary and tertiary health institutions experiencing the physiotherapy service in Lagos State Nigeria showed that 80 caregivers $(50,6 \%)$ expressed a mild burden, 75 caregivers $(47,3 \%)$ expressed that they experienced a moderate burden and 2 caregivers (2\%) expressed that they experienced a severe burden (Gbiri, Olawale, \& Isaac, 2015).

Continuous stressors among the stroke patients and their caregivers are a trigger for the burden of both, in the form of physical, emotional, social and financial burdens(Gbiri et al., 2015)(Kumar et al., 2012)(Pesantes, Brandt, Ipince, Miranda, \& DiezCanseco, 2017)(Vincent, Desrosiers, Landreville, \& Demers, 2009). The burden experienced by the caregivers is influenced by gender (female), age (elderly), low education, employment (retired), the hours of care given and mental health. The characteristics of stroke patients that influence the burden of the caregivers includes physical disorders and motor weakness and the cognitive functioning of stroke patients, depressive symptoms, decreased verbal ability, walking difficulties and neurological deficits.

Advanced stroke treatment, known as the rehabilitative phase, is a treatment that requires a long time. Patience and the continuity of care by the family needs to be applied at home. Data on the control of stroke patients to health care facilities among the population aged $\geq 15$ years in Indonesia were routinely controlled $39.4 \%(n=8,042)$, and in East Java patients who routinely controlled were slightly $40 \%(n=1,452)$ (RISKESDAS, 2018). The low patient data for routine control shows that the possibility of patients not getting maximum care may mean that they do not receive further treatment. This condition will result in the physical weakness and paralysis of stroke patients continuing to worsen, leading to complications and death. The caregivers will feel that the burden continues to increase and extend. In the end, the whole family feels the impact.

Stroke patients, caregivers and/or their families together need a comprehensive bio-psycho-sociospiritual care intervention to overcome the crisis situation created due to a stroke. Various interventions for stroke patients and their families can be obtained from the time of hospitalization up until the rehabilitation phase which continues to coordinate with public health facilities (Puskesmas). Discharge planning interventions given at the end of the acute phase of hospital care and interventions during the rehabilitation phase in the form of physiotherapy for patients, therapeutic counseling, psycho-education, skills training, and family and group supportive therapy are alternative interventions that have been proven to improve the physical condition of patients, reduce the burden of care, improve satisfaction, well-being and the quality of life of patients and their caregivers (Damawiyah, 2015)(Björkdahl, Nilsson, \& Sunnerhagen, 2007)(Suprobo, Wiyono, \& Setyanto, 2015)(Wahyuningsih, 2011). The purpose of this study was to analyze the effect of the independent ADL of the stroke patients on the burden of caregivers among the patients suffering from a stroke at home

\section{MATERIALS AND METHODS}

The study used an analytical design through a crosssectional approach. The variables included the independent activities of daily living and caregiver burden. The sample consisted of 120 informal caregivers of stroke survivors that were their relatives who stayed at home with the stroke survivor for at least 3 months. The samples were taken in 2 community health centers in Surabaya (Puskesmas Pegirian and Puskesmas Pucang Sewu) using the simple random sampling technique in the period of July - September 2018. The burden of caregiver was measured using Zarit Burden's Interview Schedule designed by Steven $\mathrm{H}$ Zarit with a 5 point rating scale ranging from never (0) through to rarely (1), sometimes (2), quite frequently (3) and nearly always (4). The burden score was categorized in 4 categories: no burden (0-21), mild to moderate burden (22-40), moderate to severe burden (41-60) and severe burden (61-80) (Kumar et al., 2012). The activities of Daily Living of the stroke survivors were measured using the Katz Index of Independence in Activities of Daily Living. It measured the 6 functions of bathing, dressing, toileting, transferring, continence and feeding. The stroke survivors were scored yes (independence/no supervision, direction or personal assistance/score 1) or no (dependence/with supervision, direction, personal assistance or total care/score 0 ) for the independence of each function. This was then classified into full function (5-6), moderate impairment (3-4) or severe functional 
impairment (2 or least)(Wallace \& Shelkey, 2006). The regression ordinal test was used to analyze the influence of the independent ADL among the stroke patients and how it related to the caregivers' burden. The ethical approval letter was granted by the Health Research Ethics commission of Health, Ministry of Health, Surabaya number: 194/S/KEPK/V/2018 date $8^{\text {th }}$ June, 2018.

\section{RESULTS}

Table 1 showed that most of the stroke patients were 56-65 years old (late elderly) (40,8\%), male $(64,2 \%)$ and with an illness lasting1-2 years (58,3\%). Almost all of the patients had had a stroke once (95\%) and most of the stroke patients had 1-2 deficit neurological conditions related to having a stroke $(56,7 \%)$.

Table 2 shows that most of the caregivers are 4655 years old (early elderly) (40,2\%), women $(75,2 \%)$, the wife of the stroke patient $(53 \%)$, educated up t senior high school (35\%) and not an employee (housewives) (47,9\%). They had been caring for 1 -2 years $(58,1 \%)$, the longest duration of caring was $1-2$ hours a day $(62,4 \%)$ and most of them had 1-2 health problems $(42,5 \%)$.

Table 3 showed that most of the independent ADLs were full functioning $(60,8 \%)$ while it was almost the same between moderate impairment and severe functional impairment at $19,25 \%$ and $20 \%$. The burden of the caregivers was mild to moderate (50\%), next to no burden at $44,2 \%$ and moderate to severe burden at $5,8 \%$.

Table 4 shows that the Chi-square value through the deviance method is 1.057 with df 2 and a significance value of 0.589 , it is concluded that the model is feasible to use.

Table 1. Characteristics of the Stroke Patients $(\mathrm{n}=120)$

\begin{tabular}{lcc}
\hline \multicolumn{1}{c}{ Variable } & n & $\mathbf{( \% )}$ \\
\hline Age (year): & & \\
36-45 years old & 9 & 7.5 \\
46-55 years old & 39 & 32.5 \\
56-65 years old & 49 & 40.8 \\
>65 years old & 23 & 19.2 \\
Gender: & & \\
Male & 77 & 64.2 \\
Female & 43 & 35.8 \\
Length of illness (year): & & \\
<1 years & 23 & 19.2 \\
1-2 years & 70 & 58.3 \\
3-4 years & 17 & 14.2 \\
>4 years & 10 & 8.3 \\
Frequency of attacks: & & \\
1-2 times & 114 & 95 \\
3-4 times & 5 & 4.2 \\
>4 times & 1 & 0.8 \\
Deficit neurology of stroke & & \\
0 symptom & 10 & 8.3 \\
1-2 symptoms & 68 & 56.7 \\
3-4 symptoms & 35 & 29.2 \\
>4 symptoms & 7 & 5.8 \\
\hline
\end{tabular}

Table 2. Characteristics of the Caregivers $(n=120)$

\begin{tabular}{|c|c|c|}
\hline Variable & $\mathbf{n}$ & $(\%)$ \\
\hline \multicolumn{3}{|l|}{ Age (year) } \\
\hline$<26$ years old & 10 & 8.5 \\
\hline 26-35 years old & 14 & 12.0 \\
\hline $36-45$ years old & 22 & 18.8 \\
\hline 46-55 years old & 47 & 40.2 \\
\hline 56-65 years old & 19 & 16.2 \\
\hline$>65$ years old & 5 & 4.3 \\
\hline \multicolumn{3}{|l|}{ Gender } \\
\hline Male & 29 & 24.8 \\
\hline Female & 88 & 75.2 \\
\hline \multicolumn{3}{|l|}{ Family relationship } \\
\hline Husband & 16 & 13.7 \\
\hline Wife & 62 & 53.0 \\
\hline Child & 25 & 21.4 \\
\hline Others & 14 & 12.0 \\
\hline \multicolumn{3}{|l|}{ Education } \\
\hline Not school & 10 & 8.5 \\
\hline Elementary school & 33 & 28.2 \\
\hline Junior high school & 24 & 20.5 \\
\hline Senior high school & 41 & 35.0 \\
\hline Diploma or Bachelor's & 5 & 4.3 \\
\hline Postgraduate & 4 & 3.4 \\
\hline \multicolumn{3}{|l|}{ Employment } \\
\hline No employee & 56 & 47.9 \\
\hline Pensioner & 2 & 1.7 \\
\hline Government employee & 6 & 5.1 \\
\hline Private employee & 18 & 15.4 \\
\hline Entrepreneurship & 34 & 29.1 \\
\hline Others & 1 & 0.9 \\
\hline \multicolumn{3}{|l|}{ Length of caring (year) } \\
\hline$<1$ year & 22 & 18.8 \\
\hline 1-2 years & 68 & 58.1 \\
\hline $3-4$ years & 17 & 14.5 \\
\hline$>4$ years & 10 & 8.5 \\
\hline \multicolumn{3}{|c|}{ Duration of caring (hour/day) } \\
\hline 1-2 hours/day & 73 & 62.4 \\
\hline 3-4 hours/day & 27 & 23.1 \\
\hline 5-6 hours/day & 9 & 7.7 \\
\hline$>6$ hours/day & 8 & 6.8 \\
\hline \multicolumn{3}{|l|}{ Health problems } \\
\hline No problem & 41 & 34.2 \\
\hline 1-2 problems & 51 & 42.5 \\
\hline 3-4 problems & 25 & 20.8 \\
\hline$>4$ problems & 3 & 2.5 \\
\hline
\end{tabular}

Table 3. Variable Descriptions $(n=120)$

\begin{tabular}{lcc}
\multicolumn{1}{c}{ Variable } & $\mathbf{n}$ & $\mathbf{\%}$ \\
\hline Independent of ADL: & & \\
$\quad$ Severe functional impairment & 24 & 20 \\
$\quad$ Moderate impairment & 23 & 19.2 \\
$\quad$ Full function & 73 & 60.8 \\
Caregiver Burden: & & \\
$\quad$ No burden & 53 & 44.2 \\
Mild to moderate burden & 60 & 50 \\
Moderate to severe burden & 7 & 5.8 \\
Severe burden & 0 & 0 \\
\hline
\end{tabular}

Table 4. Goodness of Fit

\begin{tabular}{lccc}
\hline & Chi-Square & df & Sig. \\
\hline Pearson & 1.105 & 2 & 0.575 \\
\hline Deviance & 1.057 & 2 & 0.589 \\
\hline
\end{tabular}


Table 5. Model Fitting Information

\begin{tabular}{|c|c|c|c|c|c|c|c|c|}
\hline \multicolumn{2}{|l|}{ Model } & \multicolumn{2}{|c|}{-2 Log Likelihood } & & \multicolumn{2}{|c|}{ Chi-Square } & df & Sig. \\
\hline \multicolumn{2}{|c|}{ Intercept Only } & \multicolumn{2}{|c|}{38.430} & & \multirow{2}{*}{\multicolumn{2}{|c|}{18.731}} & & \\
\hline Final & & & & & & & 2 & .000 \\
\hline \multicolumn{9}{|c|}{ Table 6. Wald Test } \\
\hline & & \multirow[t]{2}{*}{ Estimate } & \multirow[t]{2}{*}{$\begin{array}{c}\text { Std. } \\
\text { Error }\end{array}$} & \multirow[t]{2}{*}{ Wald } & \multirow[t]{2}{*}{ df } & \multirow[t]{2}{*}{ Sig. } & \multicolumn{2}{|c|}{$\begin{array}{l}\text { 95\% Confidence } \\
\text { Interval }\end{array}$} \\
\hline & & & & & & & $\begin{array}{l}\text { Lower } \\
\text { Bound }\end{array}$ & $\begin{array}{l}\text { Upper } \\
\text { Bound }\end{array}$ \\
\hline \multirow{3}{*}{ Threshold } & {$[$ No burden $=1.00]$} & .265 & .235 & 1.275 & 1 & .259 & -.195 & .726 \\
\hline & $\begin{array}{l}\text { [Mild to moderate } \\
\text { burden }=2.00]\end{array}$ & 3.734 & .506 & 54.497 & 1 & .000 & 2.743 & 4.725 \\
\hline & $\begin{array}{l}\text { [Severe functional } \\
\text { impairment =1.00] }\end{array}$ & 2.162 & .554 & 15.215 & 1 & .000 & 1.076 & 3.248 \\
\hline \multirow[t]{2}{*}{ Location } & $\begin{array}{l}\text { [Moderate } \\
\text { impairment=2.00] }\end{array}$ & .809 & .479 & 2.853 & 1 & .091 & -.130 & 1.748 \\
\hline & {$[$ Full function=3.00] } & $0^{\mathrm{a}}$ & & & 0 & . &.${ }^{a}$ & \\
\hline
\end{tabular}

Table 7. Pseudo R-Square

\begin{tabular}{ll}
\hline Cox and Snell & 0.145 \\
\hline Nagelkerke & 0.175 \\
\hline McFadden & 0.089 \\
\hline
\end{tabular}

Table 5 shows that the statistical value $G$ is 18.731 , thus it can be concluded that there is one $\beta p \neq 0$ (H1 accepted). Table 6 shows that the ADL variable within the severe functional impairment category has a significant effect on the burden of the caregiver ( $p$ value $=0.000$ ) while the ADL variable within the moderate impairment category did not have a significant effect on the burden of the caregiver ( $p$ value $=0.91$ )

Table 7 shows the determinant coefficient value of Negelkerke 0.175 or $17.5 \%$. It can be concluded that ADL with a severe functional impairment category affects the burden of the caregiver by only $17.5 \%$, while $82.5 \%$ are affected by other factors that were not included in the model test.

The interpretation of the model was done using the odds ratio test. The odd ratio of ADL with the severe functional impairment category was 3 , so it can be concluded that a caregiver who takes care of a stroke patient in the severe functional impairment category will feel burdened 3 times more than no burden. The Odd ratio of ADL within the moderate impairment category was 1 , so it can be concluded that a caregiver who takes care of stroke patients in the moderate impairment category will feel only a small burden or no burden.

\section{DISCUSSION}

The research data shows that almost all of the patients $(91.7 \%)$ had deficit neurology symptoms, with the most common symptoms being foot and/or hand weakness or paralysis (81.67\%). The characteristics of the patients included aggravated physical weakness experienced by the elderly patients (40.8\%) and most were dependent for 1-2 years after the stroke attack (58.3\%). Ischemia in most lesions in the right hemisphere or parietal lobe due to stroke biologically affect the inability of the patient to perform several physical functions such as limb movements, speech changes and changes in memory (Munir, 2018). The neuromuscular process will reduce the physiological functions of the extremities which effects the independent of ADL among the stroke patients(\& \& Bunner, 2013). Their health conditions change due to deficit neurology symptoms. There are severe stressors not only for the patients but also for their families.

The research data shows that for almost all of the patients who experienced the first attack (95\%), most of the patients were male (64.2\%) and almost all of them were the head of their family. This data can be used to aggravate the feelings of disability and helplessness due to stroke attacks. The data on the independent ADL is based on the Katz Independence Index in which the ADL shows that the 3 lowest ADLs are bathing, dressing and toilets that require adequate limb function. A real feeling of a lack of pleasure in reference to the physical difficulties after illness makes the patient feel disabled and helpless, which can improve the feelings of depression in the patients. The study by Ratnasari concluded that the majority of stroke patients had moderate depression (60\%). Their experience was that they were very dependent in terms of ADL (45\%) (Ratnasari, P; Kristiyawati, S.P.; Solechan, 2015). The weakness in the motor function is aggravated by psychological disorders. 
The majority of caregivers in this study were 46 55 years old (early elderly) (40.2\%). Women were the most common gender $(75.2 \%)$, most of the patient's education was elementary school level (36.7\%), most of the caregivers were the wife of the stroke patient (53\%), most were not employees (housewives) $(47.9 \%)$, the longest treatment was $1-2$ years (58.1\%), the most common duration of treatment was 1-2 hours a day ( $62.4 \%$ ) and most of them had 1-2 health problems (42.5\%). The results of this study are in line with the previous research which states that caregiver burden is influenced by age (elderly), gender, low education, employment (retirement), the hours spent taking care and mental health (Chow, Wong, \& Poon, 2007)(Rigby, Gubitz, \& Phillips, 2009)(Vincent et al., 2009). Family members who mainly take care of stroke patients at home feel continued stress due to their role. They can also experience strain and burden.

The regression ordinal test was computed between the independent ADL among stroke patients and caregiver burden. The results of the testing showed that ADL in the severe functional impairment category affects the burden of the caregiver by only $17.5 \%$, while $82.5 \%$ were affected by other factors that were not included in the model test. The interpretation of the model using the odds ratio test concluded that a caregiver who takes care of a stroke patient in the severe functional impairment category will feel burdened 3 times more than no burden. The results of this study are in line with the predicting factor of caregiver burden according to the characteristics of the stroke patients. This includes physical disorders such as weaknesses in the motor and cognitive functions of the stroke patients, decreased verbal ability, walking difficulties and neurological deficits (Vincent et al., 2009)(Rigby et al., 2009)(Chow et al., 2007). Independence in fulfilling the ADL, especially those that require adequate physical functioning, namely bathing, dressing and toileting, are the 3 types of ADL with the lowest independence, thus increasing caregiver burden, especially in the physical burden $(1.24 \pm 67.56)$ and emotional burden category $(0.96 \pm 74,632)$. These 3 ADL activities require greater energy related to motion and mobilization, thus aggravating the physical fatigue of the caregivers. The burden of the caregiver got worse because the caregivers also suffered from diseases including non-communicable diseases. The diseases suffered by the caregivers in this study included hypertension, diabetes mellitus, gastritis, hypercholesterolemia and hyperuricemia.

The financial burden of the patients was felt by males the most $(64.2 \%)$. They have a family role as the patriarch or husband. One of the roles of the patriarch based on the family functions is that of a wage earner (Friedman, Marilyn M; Browden, Vicky $\mathrm{R}$; Jones, 2010). This condition is in line with the previous research which states that all of the families of stroke patients experience family economic changes. This is considered to be a high stressor for families (Hariyati, Sumarwati, \& Handiyani,
n.d.)(Pambudi, 2009)(Asrul Sani, 2018). Almost all of the stroke patients in this study $(91.7 \%)$ reported the presence of sequelae, with the most common symptoms being weakness and paralysis of the feet and hands $(81.67 \%)$. The weakness or paralysis that occurs causes the patients to no longer be able to work to earn an income to finance the needs of all family members, so their role is ultimately assisted or replaced by other family members (the wife or child of the patients) through small traders at home while caring for the patient. Continued stroke care that requires long term attention will also increase the family financing both in terms of medical/control costs and the cost of transportation to visit the health care facilities.

Feelings of being helpless even related to the condition of depression in stroke patients will have an impact on the interaction of the patients and their caregivers. The caregiver in this study revealed that the patients often showed an irritable response when treated and assisted. They did not regularly take their medication, they did not want to routinely control their feelings and they did not regularly do physiotherapy or a range of motion exercises. The anger responses shown by the patients often trigger the caregivers to respond angrily. If the caregivers feel tired or bored, they may leave the patient for a moment. This is in line with the predicting factor of the caregiver symptoms of depression(Rigby et al., 2009)(Chow et al., 2007)(Vincent et al., 2009). The efforts of stroke patients to meet their needs independently according to their ability are gradually needed in the rehabilitation phase, especially related to neuro-muscular function so then the remaining symptoms of weakness/paralysis are reduced. A previous study states that stroke patients are advised to continue trying to carry out the routine control of medical personnel in order to monitor repairs or the deterioration caused by a stroke (Fadilah, Kusnanto, Nursalam, Minarti, \& Asnani, 2018). Efforts to increase independence in ADL will have a broad impact on the patients, not only related to the impact of increasing the motor skills but it will also increase self-esteem, confidence and reduce anxiety due to feelings of helplessness (Rigby et al., 2009).

The nursing interventions for families, especially for the caregivers of stroke patients, also need to be carried out together with interventions focused on the patients. The previous studies concluded that the families are more motivated and more ready to provide care at home with the provision of discharge planning at the end of the acute phase of hospital care (Damawiyah, 2015). Interventions during the rehabilitation phase come in the form of therapeutic counseling, psycho-education, skills training, family supportive therapy and health education through home visits which are alternatives that are proven to reduce the burden of care and to improve caregiver satisfaction and quality of life (Björkdahl et al., 2007). Post-stroke care at home through rehabilitation programs plays an important role in treating patients and their families at home, especially when related to 
the caregivers. Nurses at the community health center, through family health care, can provide comprehensive bio-psycho-socio-spiritual care in the rehabilitation period. This is expected to improve and maintain the fulfillment of human needs for stroke patients and their caregivers. This means that the quality of life of stroke patients, their caregivers and their families members remains optimal(Fadilah et al., 2018).

\section{CONCLUSION}

A caregiver who takes care of stroke patients with severe functional impairment will feel burdened 3 times more than feeling like there is no burden. Changes in the physical and psychological condition of stroke patients cause difficulties in terms of the independent fulfillment of ADL stroke patients. This situation causes stress to be experienced by the caregivers when caring for patients with stroke. This means that caregiver burden occurs. Nurses as family health care providers can play an important role in providing comprehensive bio-psycho-spiritual care in the rehabilitation period for stroke patients and their nurses. This is so then related diseases can reduce and improve the quality of life for stroke patients and nurses to remain in an optimal living situation.

\section{LIMITATION}

The Activities of Daily Living of stroke survivors were measured only once by the Katz Index of Independence in ADL; this was a limitation of this study. The data should be measured focused on home care and more than once, so then we can progressively evaluate the patient and caregiver's condition.

\section{REFERENCES}

Asrul Sani, M. (2018). From Family Stress to Family Strengths. Read, (February).

Badan Penelitian, \& dan Pengembangan Kesehatan, K. K. R. I. (2013). RISET KESEHATAN DASAR 2013.

Bakas, T., Clark, P. C., Kelly-hayes, M., King, R. B., Lutz, B. J., \& Miller, E. L. (2014). Evidence for Stroke Family Caregiver and Dyad Interventions. Stroke, 45, 2836-2852. https://doi.org/10.1161/STR.000000000000003 3

Björkdahl, A., Nilsson, Å. L., \& Sunnerhagen, K. S. (2007). Can rehabilitation in the home setting reduce the burden of care for the next-of-kin of stroke victims? Journal of Rehabilitation Medicine, 39(1), 27-32. https://doi.org/10.2340/16501977-0001

Chow, S. K. Y., Wong, F. K. Y., \& Poon, C. Y. F. (2007). Coping and caring: Support for family caregivers of stroke survivors. Journal of Clinical Nursing, $16(7 \quad$ B), 133-143. https://doi.org/10.1111/j.13652702.2006.01711.x
Damawiyah, S. (2015). Pengaruh penerapan discharge planning dengan pendekatan family centered nursing terhadap motivasi dan kesiapan keluarga merawat pasien stroke pasca akut di RSI Surabaya.

Fadilah, N., Kusnanto, Nursalam, Minarti, \& Asnani. (2018). Structural model of the factors related to the family resilience of stroke patients in Indonesia. Indian Journal of Public Health Research and Development, 9(11). https://doi.org/10.5958/09765506.2018.01721.7

Friedman, Marilyn M; Browden, Vicky R; Jones, E. G. (2010). Buku ajar keperawatan keluarga: riset, teori, \& praktik (5th ed.). Jakarta: EGC.

Gbiri, C. A., Olawale, O. A., \& Isaac, S. O. (2015). Stroke management: Informal caregivers' burdens and strians of caring for stroke survivors. Annals of Physical and Rehabilitation Medicine, 58(2), 98103. https://doi.org/10.1016/J.REHAB.2014.09.017

Handayani, D. Y., \& Dewi, D. E. (2009). Analisis kualitas hidup pasien dan keluarga pasca serangan stroke (dengan gejala sisa). Psycho Idea, Tahun 7 No, 35-44.

Hariyati, T. S., Sumarwati, M., \& Handiyani, H. (n.d.). Pengaruh manajemen stress terhadap kesiapan pasien stroke dan keluarga dalam merencanakan perilaku adaptif pasca perawatan di rumah sakit. Jurnal Keperawatan Indonesia, 1-8, 13-17.

Karunia, E. (2016). Hubungan Antara Dukungan Keluarga dengan Kemandirian Activity of Daily Living (ADL) Pasca Stroke. Jurnal Berkala Epidemiologi, Vol. 4(September), 213-224. https://doi.org/10.20473/jbe.v4i2.2016.213

Kumar, Sg., Roy, G., \& Kar, S. (2012). Disability and rehabilitation services in India: Issues and challenges. Journal of Family Medicine and Primary Care, 1(1), 69. https://doi.org/10.4103/22494863.94458

Munir, B. (2018). Neurologi Dasar (Edisi 2). Jakarta: Sagung Seto.

Ogunlana, M. O., Dada, O. O., Oyewo, O. S., Odole, A. C., \& Ogunsan, M. O. (2014). Quality of life and burden of informal caregivers of stroke survivors. Hong Kong Physiotherapy Journal, 32(1), 6-12. https://doi.org/10.1016/j.hkpj.2013.11.003

Pambudi, H. A. (2009). Studi fenomenologis: kecemasan keluarga pada pasien stroke yang dirawat di ruang HND Santo Lukas RS St. Elisabeth Semarang. 1-15.

Pesantes, M. A., Brandt, L. R., Ipince, A., Miranda, J. J., \& Diez-Canseco, F. (2017). An exploration into caring for a stroke-survivor in Lima, Peru: Emotional impact, stress factors, coping mechanisms and unmet needs of informal caregivers. ENeurologicalSci, 6, 33-50. https://doi.org/10.1016/J.ENSCI.2016.11.004

Ratnasari, P; Kristiyawati, S.P.; Solechan, A. (2015). Hubungan Antara Tingkat Ketergantungan Avtivity Daily Living Dengan Depresi Pada Pasien Stroke Di RSUD Tugurejo Semarang.

Rigby, H., Gubitz, G., \& Phillips, S. (2009). A systematic 
N. FADILAH, ET AL.

review of caregiver burden following stroke. International Journal of Stroke, 4(4), 285-292. https://doi.org/10.1111/j.17474949.2009.00289.x

RISKESDAS. (2018). Hasil Utama Riset Kesehatan Dasar 2018. Kementrian Kesehatan Republik Indonesia, 1(1), 1-200. https://doi.org/1 Desember 2013

Setyoadi, S., \& Wihastuti, T. A. (2018). Burnout Syndrome on Care Givers and The Fulfillment Needs of Care in The Post Stroke Patients at Physiotherapy Outpatient Ward in RST DR. Soepraoen. Jurnal Keperawatan, 9(2), 125. https://doi.org/10.22219/jk.v9i2.5208

Suprobo, K. A., Wiyono, N., \& Setyanto, A. T. (2015). Pengaruh Supportive Group Therapy terhadap
Caregiver Burden Pada Istri yang Berperan Sebagai Primary Caregiver Penderita Stroke. Jurnal Universitas Sebelas Maret, 1-12.

Vincent, C., Desrosiers, J., Landreville, P., \& Demers, L. (2009). Burden of caregivers of people with stroke: Evolution and predictors. Cerebrovascular Diseases, 27(5), 456-464. https://doi.org/10.1159/000210092

Wahyuningsih, S. A. (2011). Pengaruh Terapi Suportif terhadap Kemampuan Keluarga Merawat Klien Gagal Ginjal Kronik (GGK) Yang Menjalani Hemodialisa di Rumah Sakit Pelni Jakarta.

Wallace, M., \& Shelkey, M. (2006). Try This: Best Practices in Nursing Care to Older Adults Katz Index of Independence in Activities of Daily Living (ADL). Annals of Long Term Care, 14(11), 26-27. 